\title{
Stratigraphy and palaeoceanography of upper Maastrichtian chalks, southern Danish Central Graben
}

\author{
Jon R. Ineson, Bjørn Buchardt, Susanne Lassen, Jan A. Rasmussen, Poul Schiøler, Niels H. Schovsbo, \\ Emma Sheldon and Finn Surlyk
}

Upper Maastrichtian chalks form important hydrocarbon reservoirs in the Danish sector of the North Sea and have been intensively studied, yet their lithological uniformity can frustrate attempts to develop a high-resolution stratigraphic subdivision and a genetic understanding of the factors controlling production and sedimentation of the pelagic carbonate ooze. Recent research into these topics, supported by the Danish Energy Authority, was carried out by the Geological Survey of Denmark and Greenland (GEUS) in collaboration with the Geological Institute, University of Copenhagen by means of a multidisciplinary study involving quantitative/semiquantitative palynology, micropalaeontology (nannofossils, foraminifers) and isotope geochemistry, integrated with detailed sedimentology. Two key wells were selected, the M-10X well from the Dan Field and the E-5X well from the Tyra SE Field (Fig. 1), based on the extensive core coverage in these wells and on their position in the southern part of the Danish Central Graben where evidence of large-scale resedimentation (and consequent stratigraphic complexity) is uncommon within the Maastrichtian section.

In focusing on such a pelagic carbonate system, the ultimate aim is a holistic understanding of the marine system including temperature variation, nutrient supply and distribution, salinity, watermass layering, circulation and oxygen distribution. All these factors influence organic productivity and thus the accumulation of biogenic sediment. This study concentrated on a number of palaeoceanographic signals that can be derived from the sedimentary record, summarised in Fig. 2. Planktonic organisms, both phytoplankton (e.g. coccolithophores, some dinoflagellates) and zooplankton (e.g. foraminifers) provide a record of conditions in the upper watermasses, largely within the photic zone, while bottom conditions are indicated by epifaunal/infaunal organisms (e.g. benthic foraminifers) and bioturbation, and by the sedimentological evidence of depositional processes at the sea floor. On a larger scale, the input of terrestrial organic material relative to the marine component can provide an indirect measure of shoreline migration and thus relative sea-level change, a factor that is also reflected in the $\delta^{13} \mathrm{C}$ isotopic composition of the seawater, as recorded by the biogenic carbonate ooze.

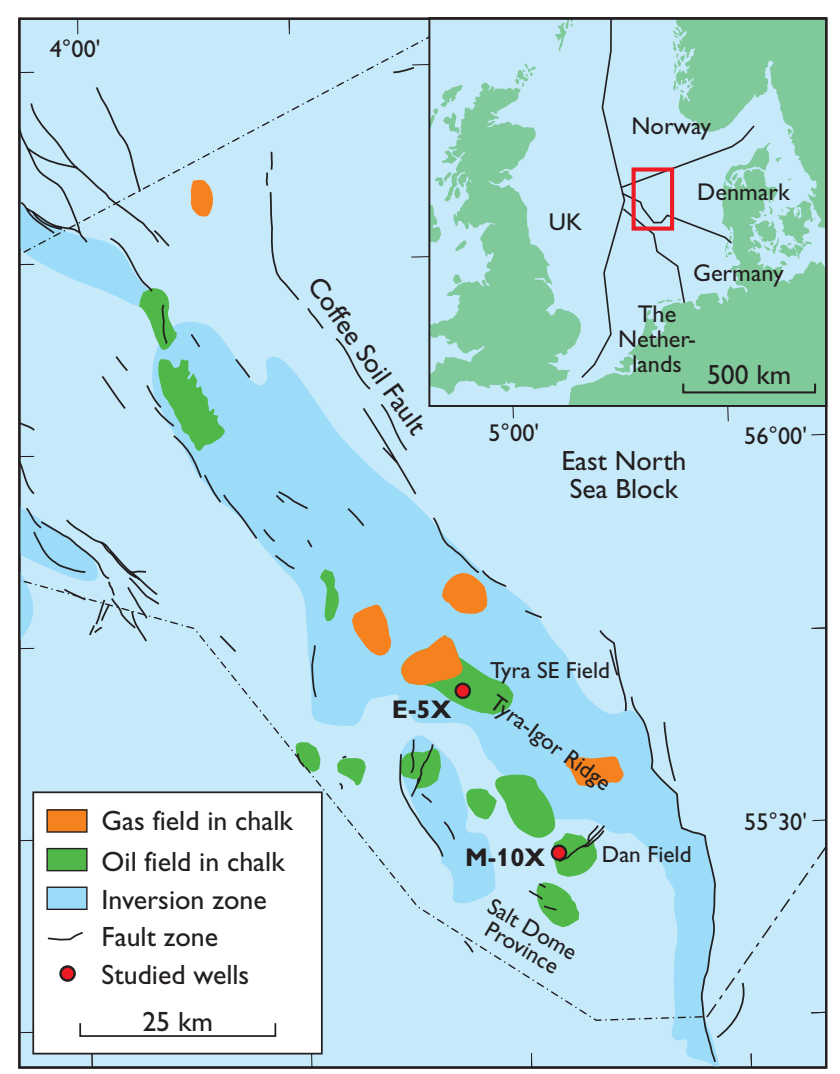

Fig. 1. Map showing the location of the two key wells, M-10X (Dan Field) and E-5X (Tyra SE Field), and the dominant Late Cretaceous structural elements in the Danish Central Graben.

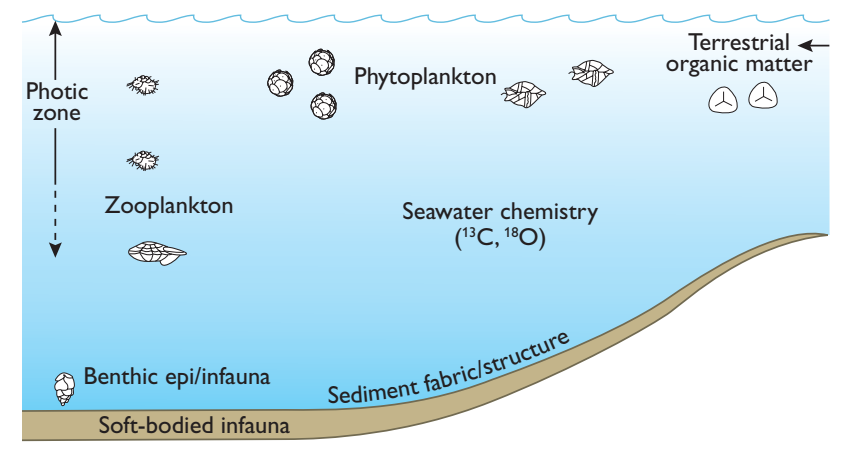

Fig. 2. Cartoon (scale arbitrary) showing the source of the palaeoceanographic signals utilised in the project; see text for explanation. 


\section{Stratigraphy}

A prerequisite for this palaeoceanographic study was a wellconstrained stratigraphic breakdown of the succession to permit confident intrabasinal correlation and comparison with regional/global events described in the literature. Although awaiting formal assignment, the upper Maastrichtian and Danian chalks of the Danish Central Graben are herein referred to the Tor and Ekofisk Formations, respectively, as defined from the Norwegian sector of the North Sea. Despite the numerous biostratigraphic studies undertaken on this stratigraphic interval in the Danish sector, much of the information is in the form of company reports, and published data

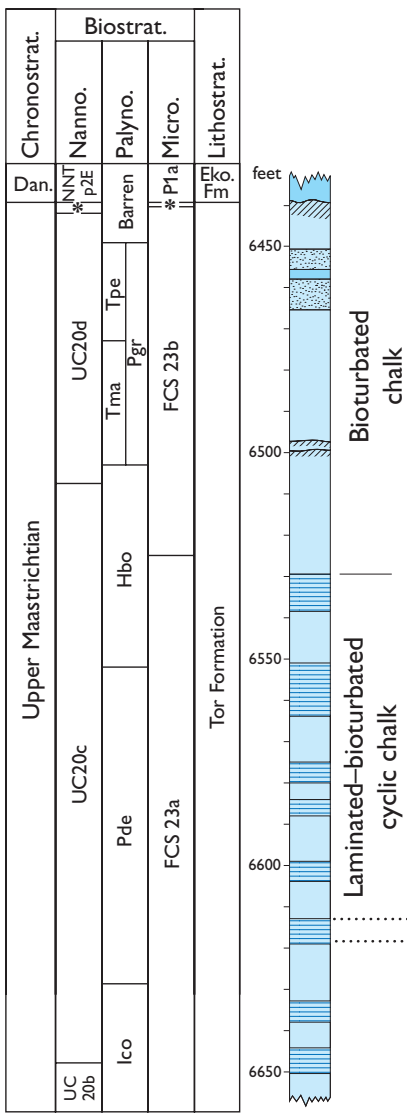

Chalk mudstone

Enhanced lam/bio cyclicity

Chalk wackestone $\pi m$ Hardground Marly chalk

Fig. 3. Stratigraphic framework of the cored upper Maastrichtian section in the M-10X well showing the broad subdivision into lower cyclic and upper non-cyclic, bioturbated chalks; the expanded section shows two laminated-bioturbated cycles, characteristic of the lower cyclic chalks. Dan., Danian; Eko., Ekofisk. Palynological zones/subzones: Ico, Isabelidinium cooksoniae; Pde, Palaeocystodinium denticulatum; Hbo Hystrichostrogylon borisii; Pgr, Palynodinium grallator; Tma, Tanyosphaeridium magdalium; Tpe, Thalassiphora pelagica. Asterisk indicates mixed floral and faunal assemblages of late Maastrichtian and Danian aspect associated with the top Tor Formation hardground. are few. A high-resolution biostratigraphic study was thus undertaken to identify internationally recognised biozones related to the dinoflagellate cyst, nannofossil and microfossil floras and faunas. Detailed stable isotope investigations were incorporated to examine the potential role of chemostratigraphy. This resulted in a consistent framework for the uppermost Maastrichtian of the two key wells in the southern Danish Central Graben, exemplified by the subdivision of the M-10X cored section shown in Fig. 3. As a supplement to the zonal biostratigraphy, semi-quantitative data provide a second tier of stratigraphic constraints; these include dinoflagellate (Palaeocystodinium denticulatum, Palynodinium grallator), foraminifer (Praebulimina laevis, Pseudotextularia elegans) and nannofossil (Watznaueria barnesiae) acme events.

The Maastrichtian-Danian boundary in the M-10X and E-5X cored sections is marked by a distinctive hardground developed in the uppermost $c .1 \mathrm{~m}$ of the Tor Formation. The association of complex cross-cutting Thalassinoides networks, the cemented and bored upper layer and the irregular, pitted, glauconite-impregnated upper surface are indicative of a mature, evolved hardground surface, recording a protracted period of non-sedimentation at the sea floor. The occurrence of mixed late Maastrichtian and early Danian faunal and floral assemblages within the uppermost metre beneath the hardground surface suggests that the burrow systems remained open into Danian time, thus accumulating complex multi-generational fills. The lowermost Danian biozones are absent above the hardground indicating that this surface remained exposed at the sea floor for at least several hundred thousand years.

\section{Palaeoceanography}

Analysis of palaeoceanographic trends and evolution in the late Maastrichtian in the study area has required integration of a wide range of detailed data, only a fraction of which can be reviewed in this summary. In the following, selected aspects of the full dataset (see Ineson et al. 2004a) are presented to provide the essential framework of the palaeoceanographic model.

\section{Sedimentology}

The upper Maastrichtian chalk succession in the southern Danish Central Graben is lithologically uniform, comprising pure coccolith-rich chalks with rare skeletal grains larger than silt grade, and a dominant 'lime mudstone' texture. In the Dan Field area, the cored upper Maastrichtian section is divisible into a lower cyclic succession, characterised by metre-scale laminated/bioturbated cycles, and an upper succession that is thoroughly bioturbated and overtly non-cyclic (Fig. 3). It has been proposed that the laminated facies in the 
lower chalks represents an alternation of thin (millimetrescale) chalk turbidites and hemipelagites; preservation of this primary sedimentary layering is thought to relate to low levels of oxygen on the sea floor (Damholt \& Surlyk 2004). The alternation of laminated and bioturbated chalks thus records rhythmic shifts in bottom-water oxygenation; subtle shifts in the floral and faunal assemblages across these cycles suggest that such changes may have been controlled by variation in the degree of watermass stratification (Ineson et al. 2004b). In addition to the lack of overt cyclicity and the ubiquitous bioturbation, the upper chalks are also lithologically more variable, including rare incipient hardground surfaces, skeletal-rich chalks (wackestones) and an isolated marly chalk bed (Fig. 3). A subtle environmental change is thus indicated from a rhythmically stratified watermass to a more homogeneous watermass under which the sea floor was well ventilated and locally/periodically influenced by weak bottom currents.

\section{Palynofacies and stable isotopes}

A number of palynological parameters can be utilised to provide a sea-level record, such as the relative proportions of marine and non-marine palynomorphs and the relative abundance of the genus Impagidinium (an indicator of open ocean conditions) within the dinoflagellate assemblages. These parameters provide a consistent sea-level signal in the two Central Graben wells (Ineson et al. 2004a). The lower, cyclic chalks record an overall gradual sea-level fall culminating in a 'peak lowstand' near the base of the P. grallator dinoflagellate Zone (Fig. 4, c. $6500 \mathrm{ft}$ ) coinciding with the level of the incipient hardground surfaces. Palynofacies data from the succeeding bioturbated chalks record a subsequent sea-level rise and a variable signal up to the barren interval at the top of the Maastrichtian section.

It has been observed widely that the carbon isotope $\left(\delta^{13} \mathrm{C}\right)$ record broadly tracks the eustatic sea-level curve (e.g. Jarvis $e t$ al. 2002). The $\delta^{13} \mathrm{C}$ values for the lower, cyclic chalks decrease gradually up-section, paralleling the palynofacies trend and adding support to the sea-level interpretation. In both wells, the lowest $\delta^{13} \mathrm{C}$ values in the upper Maastrichtian section occur just beneath the base of the $P$. grallator Zone.

\section{Nannoflora and foraminifers}

The nannofloral assemblages are diverse (average species richness of 22) and show only minor compositional fluctuations with time, reflecting overall a stable, cool water (Boreal), oligotrophic (low nutrient) setting. Subtle shifts in the relative proportions of certain taxa, however, are thought to reflect changes in the nature of the upper watermasses, and although the precise control (i.e. temperature, nutrient level, salinity) can be difficult to isolate, interpretation can be facilitated by comparison with other datasets. Two examples are shown in Fig. 4. Lucianorhabdus cayeuxii has been demonstrated to occur preferentially in relatively inshore shelf sediments (Pospichal \& Wise 1990); the general increase in the relative abundance of this species in the upper half of the studied sec-
Fig. 4. Selected data from the M-10X well, illustrating the palaeoceanographic evolution in the late Maastrichtian, as discussed in the text. For stratigraphic terms and key, see Fig. 3; the horizontal dashed line indicates the boundary between the lower cyclic and upper non-cyclic chalks. The nannofossil genera grouped together to provide an indication of changing fertility levels are Biscutum, Discorhabdus, Chiastozygus and Zeugrhabdotus.
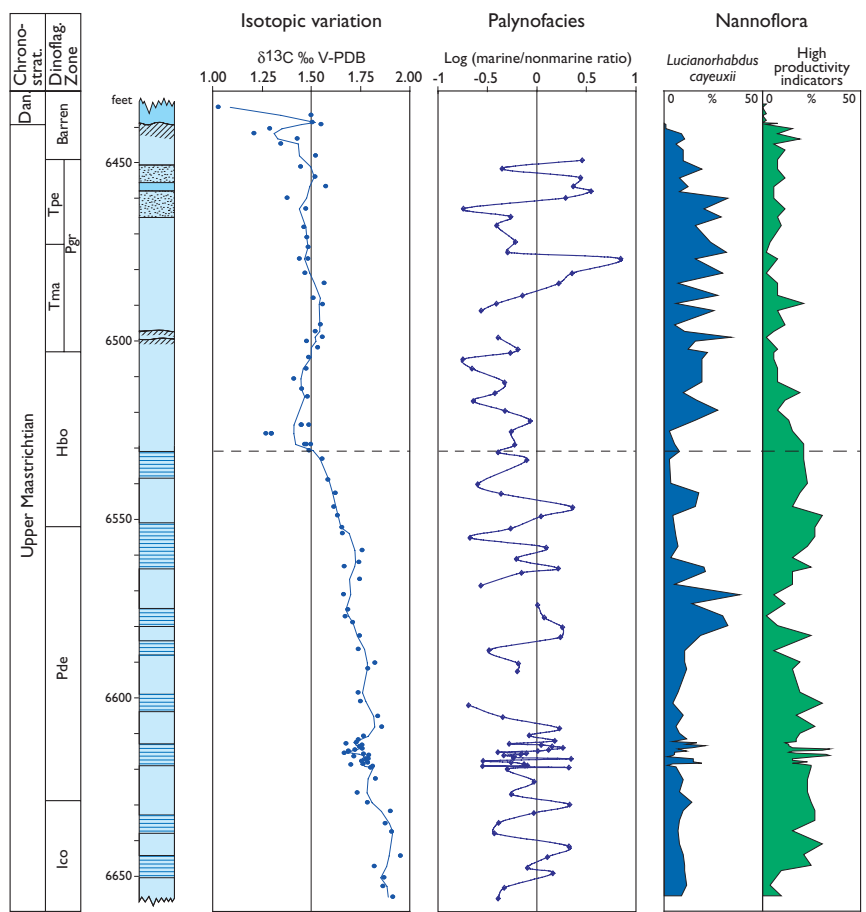

Foraminiferal faun \begin{tabular}{llllll} 
& Planktic/benthic ratio \\
0 & 20 & 40 & 60 & 80 & $100 \%$ \\
\hline
\end{tabular}

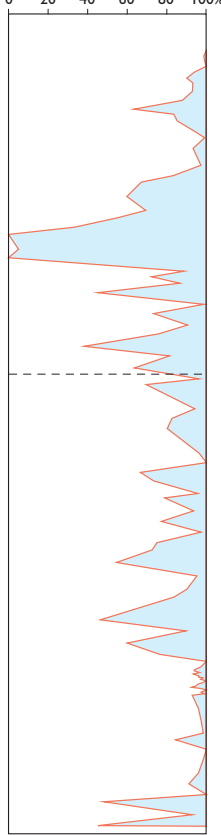


tion is thus compatible with the overall shallowing trend indicated by the sedimentological and palynological data. Certain nannofossil species are considered to be indicative of increased nutrient levels (e.g. Watkins 1989); the combined signal exhibited by these species clearly mirrors the subdivision of the succession into cyclic and non-cyclic chalks (Fig. 4 ), possibly reflecting a change in nutrient partitioning in the water column under different palaeoceanographic states.

The foraminifer assemblages are dominated by planktonic forms, particularly the ecologically tolerant Heterohelix globulosa, and plankton/benthos (P/B) ratios are typically over $70 \%$ (Fig. 4). The benthic fauna is of outer shelf aspect overall, with rare agglutinated forms. A feature of particular note in the $\mathrm{M}-10 \mathrm{X}$ foraminifer dataset is the anomalously low $\mathrm{P} / \mathrm{B}$ values at 6490-6500 ft, associated with an increase in the relative abundance of a mid-shelf benthic foraminifer, $P$. laevis. This shallowing signal from the foraminifer data coincides with the sedimentological and palynofacies data indicating the 'peak lowstand' in the late Maastrichtian chalk sea.

Acme of the planktonic foraminifer P. elegans and the nannofossil $W$. barnesiae in the upper, non-cyclic chalks are indicative of warmer surface waters in the region at this time and are symptomatic of a global warming event in the latest Maastrichtian (Huber \& Watkins 1992; Olsen et al. 2001).

\section{Late Maastrichtian palaeoceanographic evolution}

Palaeoecological data, from semi-quantitative analysis of foraminifer, coccolith and dinoflagellate faunas and floras, integrated with isotopic, palynofacies and sedimentological data has led to a model for the palaeoceanographic evolution of the Danish Central Graben in the late Maastrichtian involving two contrasting oceanographic systems. The lower half of the cored section records a cool-water, oligotrophic, deep shelf that was prone to stratification. Breakdown of this rhythmically stratified system accompanied a long-term gradual fall in sea level, perhaps reflecting a depth-related threshold beyond which stratification was no longer favoured. The upper half of the cored section records an increasingly dynamic and varied mid-shelf to deep shelf setting with a complex blend of environmental signals - sea-level change, watermass warming and evidence of low but variable productivity. Following turnover of the stratified system, the combined datasets record a progressive shallowing to a peak lowstand located just above the base of the $P$. grallator dinoflagellate Zone boundary; this sea-level event can be correlated with a key sequence boundary in the type Maastrichtian of the Netherlands (Schiøler et al. 1997).

\section{Acknowledgement}

The Danish Energy Authority (grant no.1313/01-0001) is thanked for financial support.

\section{References}

Damholt, T. \& Surlyk, F. 2004: Laminated-bioturbated cycles in Maastrichtian chalk of the North Sea: oxygenation fluctuations within the Milankovitch frequency band. Sedimentology 51, 1323-1342.

Huber, B.T. \& Watkins, D.K. 1992: Biogeography of Campanian-Maastrichtian calcareous plankton in the region of the Southern Ocean: paleogeographic and paleoclimatic implications. In: Kennett, J.P. \& Warnke, D.A. (eds): The Antarctic paleoenvironment: a perspective on global change. Antarctic Research Series 56, 31-60.

Ineson, J.R., Buchardt, B., Lassen, S., Rasmussen, J.A., Schovsbo, N.H., Schiøler, P., Sheldon, E. \& Surlyk, F. 2004a: Palaeontology, stable isotopes and sedimentology of the Upper Maastrichtian, Danish Central Graben: a record of palaeoclimatic and palaeoceanographic change. Danmarks og Grønlands Geologiske Undersøgelse Rapport 2004/81, $20 \mathrm{pp}$.

Ineson, J.R., Buchardt, B., Lassen, S., Rasmussen, J.A., Schovsbo, N.H., Schiøler, P., Sheldon, E. \& Surlyk, F. 2004b: On the origin of laminated-bioturbated chalk cycles in the Upper Maastrichtian, Danish Central Graben. Danmarks og Grønlands Geologiske Undersøgelse Rapport 2004/82, 22 pp.

Jarvis, I., Mabrouk, A., Moody, R.T.J. \& de Cabrera, S. 2002: Late Cretaceous (Campanian) carbon isotope events, sea-level change and correlation of the Tethyan and Boreal realms. Palaeogeography, Palaeoclimatology, Palaeoecology 2948, 1-34.

Olsen, R.K., Wright, J.D. \& Miller, K.G. 2001: Paleobiogeography of Pseudotextularia elegans during the latest Maastrichtian global warming event. Journal of Foraminiferal Research 31, 275-282.

Pospichal, J.J. \& Wise, S.W. 1990: Maastrichtian calcareous nannofossil biostratigraphy of Maud Rise ODP Leg 113 Sites 689 and 690, Weddell Sea. Proceedings of the Ocean Drilling Program, Scientific Results 113, 465-487.

Schiøler, P., Brinkhuis, H., Roncaglia, L. \& Wilson, G.J. 1997: Dinoflagellate biostratigraphy and sequence stratigraphy in the type Maastrichtian (Late Cretaceous), ENCI Quarry, The Netherlands. Marine Micropaleontology 31, 65-95.

Watkins, D.K. 1989: Nannoplankton productivity fluctuations and rhythmically-bedded pelagic carbonates of the Greenhorn Limestone (Upper Cretaceous). Palaeogeography, Palaeoclimatology, Palaeoecology 74, 75-86.

\footnotetext{
Authors' addresses

J.R.I., P.S., N.H.S. \& E.S., Geological Survey of Denmark and Greenland (GEUS), Øster Voldgade 10, DK-1350 Copenhagen K, Denmark. E-mail: ji@geus.dk B.B. \& F.S., Geological Institute, University of Copenhagen, Øster Voldgade 10, DK-1350 Copenhagen K, Denmark.

S.L., 96 Settrington Road, London SW6 3BA, UK.

J.A.R., Geological Museum, University of Copenhagen, Øster Voldgade 5-7, DK-1350 Copenhagen K, Denmark.
} 